\title{
ДІАЛОГІЗАЦЯ НАВЧАННЯ НА ПРАКТИЧНО-СЕМІНАРСЬКИХ ЗАНЯТТЯХ МАЙБУТНІХ УЧИТЕЛІВ ФІЛОЛОГІЧНИХ СПЕЦАЛЬНОСТЕЙ ЯК УМОВА ФОРМУВАННЯ ДИДАКТИЧНОЇ КОМПЕТЕНТНОСТІ
}

Мішеніна Т. М. Діалогізація навчання на практично-семінарських заняттях майбутніх учителів філологічних спеціальностей як умова формування дидактичної компетентності.

У статті розкрито сутність поняття «діалогізація навчання»; діалогізацію навчання обгрунтовано як дидактичну умову формування дидактичної компетентності майбутніх учителів філологічних спеціальностей. Висвітлено аспектуальні складники дидактичного дискурсу у процесі гуманітарної підготовки майбутніх фахівців.

Ключові слова: діалогізація навчання, практичне і семінарське заняття, майбутні вчителі філологічних спеціальностей, дидактичний дискурс, дидактична компетентність.

Мишенина Т.М. Диалогизация обучения на практическо-семинарских занятиях будущих учителей филологических спеціальностей как условие формирования дидактической компетентности.

В статье раскрыта сущность понятия «диалогизация обучения»; диалогизация обучения обоснована как дидактическое условие формирования дидактической компетентности будущих учителей филологических специальностей. Осветлены аспектуальные составляющие дидактического дискурса в процессе гуманитарной подготовки будущих специалистов.

Ключевые слова: диалогизация обучения, практическое и семинарское занятия, будущие учителя филологических специальностей, дидактический дискурс, дидактическая компетентность.

Mishenina T. M. Dialogization of education during practical exercises and seminars of future teachers of philological specialties as a condition of the formation of didactic competence.

The article reveals the essence of the concept of «learning dialogization»; dialogization justified as a didactic training for building a didactic competence of future teachers philological specialties. Lightened aspectual components didactic discourse in humanitarian training of future professionals.

Key words: dialogization learning iseminarskoe practical lessons, future teachers philological specialties, didactic discourse, teaching competence.

3-поміж основних завдань вишів визначальним $є$ підготовка випускника-спеціаліста, професіонала, забезпечивши високий рівень сформованості таких якостей особистості майбутнього фахівця: прагнення до самовдосконалення і творчої самореалізації; критичність мислення; оперування новітніми технологіями (залежно від професійної спрямованості) й активне їх використання у професійній діяльності; готовність забезпечити позитивнонормативне ставлення до інших членів суспільства; високий рівень сформованості дидактичної компетентностей і професійної компетенції; креативність, поліваріативність щодо застосування набутих умінь та навичок тощо.

Поважне ставлення сучасної активної молоді до професії вчителя об'єктивно пов'язане 3 приналежністю вчителів до інтелектуальної еліти суспільства, носіїв культури думки, оскільки, поза жодними сумнівами, учитель становить взірець для кожної особистості.

Аналіз наукових джерел з психології, дидактики, лінгвістики, лінгводидактики засвідчує, що в теорії і практиці вищої освіти накопичено значний досвід, який може стати основою модернізації гуманітарної підготовки студентів філологічних факультетів: висвітлено психологічні аспекти проблеми комунікативного вдосконалення особистості (О. Потебня, О. Синиця, Г. Костюк, Л. Проколієнко, Л. Виготський, І. Гальперін, О. Леонтьєв, С. Рубінштейн, І. Зимня, С. Климов, В. Слободчиков, С. Смирнов, Г. Колшанський); визначено дидактичні засади підготовки майбутнього вчителя в системі вищої освіти (А. Алексюк, О. Савченко, О. Сухомлинська, М. Свтух, П. Підкасистий, В. Галузинський, 
М. Лещенко, О. Пєхота, О. Пометун); досліджено способи і шляхи формування лінгвістичних та прагмалінгвістичних умінь учнів і студентів (М. Плющ, Н. Тоцька, М. Муравицька, В. Русанівський, О. Пономарів, Л. Мацько, В. Мусієнко, Ф. Бацевич, О. Селіванова, Л. Паламар).

Теоретичним питанням динаміки дидактичної компетентності майбутніх учителів філологічних спеціальностей приділялася належна увага з боку психологів, лінгвістів, науковців-методистів. Однак, незважаючи на конструктивні досягнення, у вітчизняній дидактиці відсутні системні наукові праці, у яких з'ясовано питання змісту, принципів, методів, форм, тобто технології формування дидактичної компетентності майбутніх учителів-словесників.

Meта cmammi - обгрунтувати процес діалогізації навчання як умову формування дидактичної компетентності майбутніх учителів філологічних спеціальностей у процесі гуманітарної підготовки.

Під час вивчення конкретних тем у змісті навчального предмета важливе місце відводиться закріпленню знань, умінь і навичок, що здійснюється на практичнолабораторних заняттях. Якщо основна мета лекційного курсу полягає в забезпеченні повноцінної орієнтації майбутніх філологів у теоретичних проблемах виучуваного курсу, то призначення практично-лабораторних занять - їх активне включення в практичне оволодіння цими знаннями.

Визначаємо такі завдання практично-семінарських занять у прочесі підготовки майбутніх учителів філологічних спеціальностей:

a) дидактичне - розширити й поглибити теоретичні знання, отримані студентами в лекційному курсі і в процесі самостійної роботи з довідковими й науковими джерелами; формувати на основі здобутих знань переконання, навички продуктивного мислення, дискусії, формувати наукову картину світу;

б) практичне - формувати навички шляхом запровадження фахово орієнтованих завдань, розвивати навички творчої професійної діяльності; оволодіти навичками конспектування першоджерел, ведення дискусії, комунікації 3 викладачами й однокурсниками;

в) розвивальне - навчити студентів порівнювати, аналізувати окремі положення, факти, теорії, підходи; розвивати їхні професійно-креативні якості;

г) контрольне - забезпечити перевірку якості сформованості відповідних компетенцій за допомогою опитування та інших форм контролю.

Практичне заняття становить таку форму навчальної взаємодії, за якої викладач організовує розгляд студентами окремих методичних теоретичних положень і формує вміння й навички їх практичного застосування шляхом індивідуального виконання відповідно до сформульованих завдань. Практичне заняття дозволяє більш повно врахувати індивідуальні риси особистості майбутнього фахівця, забезпечує умови цілеспрямованого розвитку його професійного мислення й пізнавальної мотивації.

У традиційній системі навчання у ВПНЗ провідна роль у розробленні і проведенні практичних занять належить викладачеві, а студенти є більш чи менш активними його учасниками. Креативно-інноваційна стратегія організації навчального процесу передбачає здійснення механізму його діалогізащії.

Розглянемо більш детально зміст механізму діалогізації навчального процесу з позиції психології.

За нашим спостереженням, у найбільш відомих концепціях структури спілкування подано три визначальних компоненти (функції, сторони, складники). Так, В. М'ясищев виокремлює три фундаментальні виміри (характеристики, параметри) спілкування: комунікативне відображення, комунікативне звертання й комунікативне ставлення [12]. Г. Андреєва [1] розглядає у складі спілкування комунікативну, інтерактивну й перцептивну сторони. Я. Коломінський характеризує когнітивну, регулятивну й афективну функції [8]. Н. Обозов описує гностичний, поведінковий й афективний 
компоненти [13]. А. Бодалєв виокремлює гностичний, праксіологічний й афективний компоненти спілкування [2]. Б. Ломов - інформаційну, регулятивну й афективну функції $[10 ; 11]$. Подані групи функцій спілкування наближаються за структурою до структури «мовного поєднання» К. Бюлера [4], яка охоплює пізнавальну, експресивну й імпресивну функції.

Здійснений психологічний аналіз наведених груп компонентов спілкування засвідчує, що за своєю психологічною сутністю і смислом вони максимально наближаються. Тому їх можна вважати різновидами окресленої парадигми структури і функцій спілкування, що виражає зміст інформаційно-пізнавального, регулятивно-поведінкового й емоційноафективного компонентів структури спілкування.

Уявлення про поведінково-регулятивну й інтерактивно-дієву функції спілкування пов'язане 3 виявами суб'єктної активності участників спілкування і з особливостями їх взаємодії. При цьому аналізуються особливості техніки комунікації і форми соціальної організації взаємодії, а ефекти власне людського взаєморозуміння і взаємодії переважно не позначені посиленою увагою i тому особистісно-діалогічний зміст спілкування залишається редукованим.

Можливими є різноманітні поєднання інформаційно-пізнавальних, поведінковорегулятивних i емоційно-афективних виявів спілкування, водночас визначальним чинником можливої інтерсуб'єктності-діалогічності різноманітних констеляцій цих функцій наявність екзистенційно-онтологічних, особистісно-смислових компонентів та роль, яку вони відіграють у кожній конкретній композиції різноманітних функцій спілкування. Детермінація діалогізації різноманітних констеляций функцій спілкування інтерсуб'єктними (екзистенційно-онтологічними) активаторами майже ніколи не подана іманентно, більш традиційно є лише заданою, можливою або варіативною. Реалізація цієї потенціальності визначається виявами інтерсуб'єктно-діалогічної релятивності процесуальності, контекстуальності і співвідношенням суб'єктності учасників спілкування.

Узагальнюючи викладене вище, поділяємо думку Г. Дьяконова стосовно змісту i механізмів реалізації функцій спілкування [6, с. 227-242]. Зокрема діалогічне спілкування можна розглядати як чотирикомпонентну структуру, у якій до традиційної тріади компонентів (інформаційно-пізнавального, поведінково-регулятивного й емоційноафективного) додається функція спілкування - особистісно-смислова, інтерсуб'єктнодіалогічна. Окреслена функція відіграє роль системоутворювального чинника стосовно інших виявів процесу спілкування, оскільки визначає і структурує змістовні особливості цього спілкування як особливості діалогічного спілкування.

Викладене вище дозволяє розробити рівень активності майбутніх учителів філологічних спеціальностей у діалогічному навчанні, що визначається дотриманням таких вимог:

1) відтворення фахово орієнтованого середовища, у якому учасники діалогу виконують ролі носіїв конкретних соціальних і професійних ролей;

2) урахування психолого-вікових особливостей, рівня підготовленості студентів, розвитку їхнього творчого потенціалу.

Це сприяє формуванню в майбутніх учителів комунікативних навичок, умінь висловлювати власні погляди на розв'язання навчальної проблеми, розкривати, аргументувати і відстоювати свою позицію. У діалогічній взаємодії активізуються когнітивні процеси: сприйняття, увага, уява, інтуїція, антиципація, пам'ять, розвивається творче мислення, накопичується досвід нестандартного розв'язання навчальних завдань професійно-методичного спрямування, знижується почуття напруги в спілкуванні 3 однокурсниками й викладачами. Відбуваються динамічні зміни в емпатійній сфері особистості: посилюється позитивна установка на розуміння інших людей, співчуття, співпереживання й співдію; зростає толерантність й увага до чужої думки, гнучкість у спілкуванні. Розвиваються креативні якості екзистенціальної сфери: зростає упевненість 
молоді у власних інтелектуальних і творчих силах, самоповага, відбувається взаємне утвердження «Я-концепції» учасників діалогу.

Практичне заняття діалогічного типу, передбачаючи взаємодію й спілкування його учасників як рівноправних індивідуальностей - носіїв унікального особистісного досвіду, також зорієнтоване на їхній особистісний і професійний розвиток. Заснований на взаємній повазі, довірі, відкритості і взаєморозумінні комунікантів, діалог є засобом їхнього взаєморозкриття i взаємоутвердження. Діалогізація навчання розкриває широкі можливості щодо всебічного розвитку студентів, зокрема творчого мислення й готовності до майбутньої професійної діяльності. Усе ие надає змогу визначити навчальний діалог як доиільну форму побудови практичних занять у процесі гуманітарної підготовки майбутніх учителів філологічних спеціальностей.

У процесі дослідного навчання 3'ясовано, що найбільший вплив на формування професійно-креативних здібностей майбутніх учителів філологічних спеціальностей мають на:

а) інтелектуально-креативні якості - евристична бесіда, сократівський діалог, мозковий штурм тощо;

б) критичне і творче мислення - проблемно-аналітична і проблемна бесіда, практичні заняття діалогічного типу;

в) комунікативно-креативні здатності - практичне заняття за моделлю діалогу, дискусія та її різновиди;

г) екзистенціально-креативні якості - індивідуальна мозкова атака, автентична бесіда, «Монолог відкривача», самоспостереження, «Діалог із самим собою».

Дидактична компетентність майбутніх учителів філологічних спеціальностей формується засобом взаємодії адресанта/адресата в педагогічному процесі, способом передавання i сприйняття інформації у процесі спілкування. Саме розуміння філософських і лінгвопсихологічних основ його природи й сутності визначає основні позиції побудови дидактичної моделі розвитку професійних умінь майбутнього вчителясловесника, його фахової компетенції, комунікативної вправності. Визначення характеру взаємодії й особливості співпраці основних учасників навчальної комунікації, продукторів дидактичного дискурсу: адресанта (учителя-словесника, викладача) - адресата (учнів, студентів-філологів).

Комунікативний акт особистості структурується на основних позиціях, що враховують код мовленнєвої діяльності, контекст, саме повідомлення, контакт між основними учасниками процесу спілкування - адресантом/адресатом. Комунікативне завдання, що $\epsilon$ однією із функціональних одиниць комунікативного акту, може бути реалізованим у ситуації дидактичної взаємодії через дидактичні завдання, достатній рівень педагогічного спілкування адресанта/адресата.

Грунтовно дослідивши лінгвістичні основи рівнів контекст - повідомлення - код комунікації (модель дидактичного дискурсу Р. Якобсона), уважаємо, що сутність дидактичної компетентності та рівень іiі сформованості, тобто критерії комунікативної компетенції студентів філологічних факультетів не можуть бути чітко окресленими та визначеними без урахування висновків про сутність контакту комунікаторів як потенційних учасників комунікативного акту в межах дидактичного дискурсу.

Суттєво розширюють наше уявлення про сутність механізму формування дидактичної компетентності майбутніх учителів філологічних спеціальностей філософські основи природи спілкування. Спілкування є однією з важливих умов формування суспільства в цілому й особистості зокрема. Це процес взаємозв'язку та взаємодії суспільних суб'єктів, під час якого відбувається обмін інформацією, досвідом, здібностями, уміннями й навичками, а також результатом діяльності. Спілкування виявляється у двох основних формах: у формі повідомлення (передача інформації) і формі залучення, тобто у формі, що передбачає участь осіб у спільній діяльності. На основі спільної творчості, участі в діяльності 3 іншими можливе емоційно-моральне взаємопорозуміння. 3 огляду на це, 
спілкування слід розглядати в контексті 3 філософською категорією «взаємодія», що визначається як процес взаємного впливу. Взаємодія становить кінцеву причину всього того, що існує. С декілька форм взаємодії: загальний зв'язок явищ, рух, зміна, функціональна залежність.

Отже, спілкування в цілому й дидактичне спілкування може визначатися як процес взаємодії, у результаті чого відбувається перетворення стану кожного партнера на максимально можливу наближеність до спільного стану, що становить спільність, узгодженість у думках, оцінках. Тобто, у результаті спілкування відбувається не просто обмін думками, ідеями, а перетворення стану кожного суб'єкта (об'єкта) на їх співмірне надбання, спільний досвід, спільні знання.

Узагальнюємо, що основною функцією спілкування (дидактичного спілкування) 3 позиції комунікативної філософії є зміна одним із суб'єктів (адресантом - викладачем) поглядів, переконань, дій, знань, умінь та навичок іншого суб'єкта (адресата - студента) або у власних інтересах, а як правило, в інтересах соціуму.

Говорячи про лінгвопсихологічні основи природи спілкування, констатуємо неоднозначність тлумачень, що визначають природу спілкування. Так, наприклад, Б. Ломов розуміє спілкування як взаємодію адресанта/адресата [11]. І. Зимня вказує на спілкування як на форму взаємодії між учасниками комунікативних актів [5]. Л. Буєва зазначає, що спілкування - це «процес взаємодії і взаємозв'язку суспільних об'єктів (класів, груп, особистостей), у якому відбувається обмін діяльністю, інформацією, досвідом, здібностями, вміннями та навичками, а також результатами діяльності» [3, с. 447]. У пропонованій роботі орієнтуємося на обгрунтування природи спілкування, запропоноване О. Леонтьєвим [9], який справедливо вважає спілкування діяльністю. Науковець виокремлює такі характеристики спілкування як діяльності:

а) інтенціональність (наявність конкретної мети та специфічних мотивів);

б) результативність (міра збігання досягнутого результату з означеною метою);

в) нормативність (необхідність соціально-психологічного контролю за перебігом і результатом акту спілкування) [9, с. 27].

Підсумовуючи, констатуємо, що розуміння природи спілкування як діяльності надає змогу проаналізувати його основні категорії, характеристики. Основними ж категоріями спілкування є діяльність, взаємодія, взаємостосунки, суспільні стосунки, взаємооцінка.

Спілкування в сучасному мовному просторі вже є не тільки формою людської взаємодії, оскільки становить функціональну категорію. Саме функціональним і професійно значущим $\epsilon$ спілкування у педагогічній діяльності.

Основною метою комунікативної діяльності в ситуації дидактичної комунікації між адресантом/адресатом є прагнення до зміни і власне зміна поведінки адресанта (студента). Ідеться насамперед про зміну (у напрямку динаміки) мовної й літературознавчої картин світу, наповнення її новими й новими ілюстраціями, оновленим категорійний апаратом, прийняття та трансформацію до внутрішніх кодів тієї інформаційної бази, яку пропонує адресант.

Провідним засобом у процесі комунікативної діяльності $є$ мовлення адресанта/адресата (вербальне - невербальне). У мовленні постає результат інформаційної передачі повідомлення, через мовлення адресата адресант може з'ясовувати ступінь навченості, характер засвоєння та рівень нормативності відображення мовних кодів.

Об'єктом комунікативної діяльності є текст. Мовлення транслюється, тобто породжується та передається за допомогою висловлювання, на яке в адресата виникає зворотня реакція, що виявляється у вербальному мовленні через текст.

Результатом комунікативної діяльності $є$ прийняття адресатом тих настанов, що пропонує адресант: сприйняття інформації, іiі перероблення, запам'ятання, уміння відтворити через повідомлення.

Взаємодія основних учасників комунікативних актів дидактичного дискурсу здійснюється у ситуації дидактичного спілкування, результатом якого є прийняття тих настанов, що пропонує викладач. Обрання необхідного типу настанови (готовність 
реагувати певним способом в однотипній ситуації) адресанта під час мовленнєвого спілкування $є$ одним із важливих чинників ефективності педагогічного спілкування загалом.

Дослідники виокремлюють два основних типи настанов, що діють у галузі адресант/адресат повідомлення в ситуації дидактичної комунікації:

a) позитивна настанова (адресант сприяє комунікації за допомогою як вербальних (підтримка словом, запитанням тощо), так і невербальних (посмішка, доброзичливий погляд) засобів, часто намагається редагувати мовлення адресата та виправляти його, що має достатньо високий навчальний ефект);

б) негативна настанова (адресант приділяє адресату мало уваги та часу в процесі спілкування, не помічає прогресивних тенденцій у засвоєнні матеріалу, не заохочує адресата, не працює з ним належно). Досліджуючи систему взаємодії адресанта/адресата в ситуації дидактичної комунікації, вказуємо на важливість питання про сутність та функції власне дидактичного спілкування, оскільки саме воно $\epsilon$ показником професійної компетенції студентів-філологів, i, зокрема, дидактичної компетентності.

Інтерпретуючи зміст механізму формування дидактичної компетентності майбутніх учителів філологічних спеціальностей, акцентуємо увагу на механізмі професійнопедагогічного спілкування як системи (прийоми та навички) органічної соціальнопсихологічної взаємодії педагога і тих, хто навчається, змістом якої є обмін інформацією, здійснення виховного впливу, організація взаємостосунків за допомогою комунікативних засобів» [7, с. 12].

Фахово орієнтоване спілкування - це форма навчальної взаємодії, співпраці вчителя й учнів. Педагогічне спілкування є особистісно та соціально орієнтована взаємодія; одночасно реалізує комунікативну, перцептивну й інтерактивну функції, послуговуюючись сукупністю вербальних засобів» [5, с. 433].

Фахово орієнтований дидактичний дискурс забезпечує ефективність процесу навчання та взаємодії викладач/студент - функцію фасилітації (англ. facilitate - полегшувати). Дійсно, основними вимогами до науково-педагогічних працівників є наявність власного досвіду $\mathrm{i}$ прийняття особистісно спрямованого способу життя як у внутрішньому плані, так i в міжособистісних стосунках, зокрема професійних. Все це впливає на розвиток основних якостей адресанта (викладача):

а) конгруентності (умінь поєднувати в собі образ викладача-професіонала і власне особистість, яка забезпечує динаміку іншої особистості);

б) емпатії (здатності відчувати почуття іншої людини, співпереживати, не бути байдужим).

Викладач у ролі фасиліфікатора в межах дидактичного спілкування має допомогти оволодіти навчальним матеріалом, допомогти вчитися самостійно, увиразнити себе як особистість, зацікавити, підтримати, самоактуалізуватися на сприйняття інформації.

Особливість дидактичного дискурсу виявляється насамперед у його фаховому спрямуванні. Узагальнюючи, зауважимо, що дидактичне спілкування в умовах вищого навчального закладу характеризується потрійною спрямованістю на саму навчальну взаємодію, на тих, хто навчається (іхній актуальний стан, перспективні лінії розвитку) і на предмет засвоєння. Водночас діалогізація навчання у процесі гуманітарної підготовки майбутніх учителів філологічних спеціальностей визначається особистісною, соціокультурною, предметною орієнтацією iї суб'єктів.

Отже, оптимізація взаємодії позицій адресант/адресат дидактичного дискурсу забезпечує реалізацію контактовстановлювальної функції, що засвідчує високий рівень сформованості дидактичної компетентності майбутнього вчителя-словесника - сформовані навички дидактичного дискурсу. При цьому ефективність дидактичної комунікації залежить від високого ступеня гармонізації рольових настанов учасників навчального спілкування.

Перспективами подальших досліджень є розроблення механізму реалізації діалогічного навчання під час лекційного подання навчальної інформації (зміст і структурування 
лекційних навчальних текстів) у процесі підготовки майбутніх учителів філологічних спеціальностей.

Література
1. Андреева Г. М. Социальная психология / Г. М. Андреева. - М. : Изд-во МГУ, 1980. - 415 с. 2. Бодалев А. А. Личность и общение : Избранные труды / А. А. Бодалев. - М. : Педагогика, 1982. - 212 с. 3. Буева Л. П. Общение // Философский энциклопедический словарь / Л. П. Буева. - М. : Сов. энциклопедия, 1983. - С. 447-448. 4. Бюлер К. Теория языка. Репрезентативная функция языка / К. Бюлер ; [пер. с нем. О.С. Филоненко ; общ. ред. и коммент. Т. В. Булыгиной]. - М. : Прогресс, Универс, 1993. - 502 с. 5. Дьяконов Г.В. Основы диалогического подхода в психологической науке и практике : дис. ... доктора психол. наук : 19.00.01 - «Общая психология, история психологии». - К., 2009. - 573 с. ; С. 227-242. 6. Зимняя И. А. Педагогическая психология / И.А. Зимняя. - М., 2003. - 384 с. 7. Кан-Калик В. А. Учителю о педагогическом общении : [кн. для учителя] / В. А. Кан-Калик. - М. : Просвещение, 1987. - 190 с. 8. Коломинский Я. Л. Социальные эталоны как стабилизирующие факторы «социальной психики» / Я. Л. Коломинский // Вопросы психологии. - 1972. - № 1. - С. 99-110. 9. Леонтьев А. А. Язык и речевая деятельность в общей и педагогической психологии: Избр. псих. труды / А. А. Леонтьев. - М. : Московский психо-социальный институт ; Воронеж : НПО «МОДЭК», 2001 - 448 с. 10. Ломов Б. Ф. Идеи и методы кибернетики в психологии и педагогике / Б. Ф. Ломов // Кибернетика на службе коммунизма. - М. - 1981. - № 4. - С. 34-56. 11. Ломов Б. Ф. Теоретические и методологические проблемы психологии / Б. Ф. Ломов. - М. : Наука, 1984. - 444 с. 12. Мясищев В. Н. Психология отношений / В. Н. Мясищев ; [под ред. А. А. Бодалева, вступ. статья А. А. Бодалева]. - М. : Изд-во «Институт практической психологии», Воронеж : НПО «МОДЕКС», 1995. - 356 с. 12. Обозов Н. Н. Межличностные отношения / Н. Н. Обозов. - Л. : Изд-во ЛГУ, 1979. - 151 с. 13. Роджерс К. Эмпатия // Психология эмоций. Тексты / К. Роджерс / [под. ред. В. К. Вилюнаса, Ю. Б. Гиппенрейтер]. - М., 1984. - С. 235-237. 14. Фурмановская Н. И. Коммуникативно-прагматические аспекты единиц общения / Н. И. Фурмановская. - М., 1998. $-314 \mathrm{c}$.

УДК 378.147

К. О. Морозова, здобувач,

Н. І. Зеленкова, кандидат пед. наук, доцент, Криворізький педагогічний інститут ДВНЗ «Криворізький начіональний університет»

\section{ДИДАКТИЧНА МОДЕЛЬ ФОРМУВАННЯ ІНФОРМАЦИЙНО-КОМУНІКАЦІЙНИХ КОМПЕТЕНТНОСТЕЙ СТУДЕНТІВ У ПРОЦЕСІ ВИВЧЕННЯ ПСИХОЛОГО- ПЕДАГОГІЧНИХ ДИСЦИПЛІН}

Морозова К. А., Зеленкова Н. І. Дидактична модель формування інформаційно-комунікаційних компетентностей студентів у процесі вивчення психолого-педагогічних дисциплін.

У статті проаналізовано поняття «дидактична модель» та вимоги до іiі формування. Подано проект дидактичної моделі формування інформаційно-комунікаційних компетентностей студентів у процесі вивчення психолого-педагогічних дисциплін.

Ключові слова: дидактична модель, інформаційно-комунікаційна компетентність, навчальний сайт.

Морозова К. А., Зеленкова Н. И. Дидактическая модель формирования информационнокоммуникационных компетентностей студентов в процессе изученя психолого-педагогических дисциплин.

В статье проанализировано понятие «дидактическая модель», и условия её формирования. Представлен проект дидактической модели формирования информационно-коммуникационных компетентностей студентов в процессе изучения психолого-педагогических дисциплин.

Ключевые слова: дидактическая модель, информационно-коммуникационная компетентность, учебный сайт. 